\title{
JORNADA PARA A NOITE
}

George Monteiro*

O'NEILL, E., (1993) Jornada para a Noite, Jorge de Sena, (tradução), Mécia de Sena (introdução). Lisbon, Livros Cotovia/ Teatro Nacional D. Maria II, 1992. 193p.

To what Mécia de Sena calls Jorge de Sena's "dramatic universe" - to distinguish it from his other literary and cultural universes - can now be added this important piece. The publication of this translation of Eugene O'Neill's Long Day's Journey Into Night brings it within the context of Sena's own plays ( $O$ Indesejado and six one-acts), his substantial body of theater reviews and criticism (collected posthumously in 1989 as Do Teatro em Portugal, a volume that includes two 1958 pieces on Long Day's Journey and one 1947 piece on Anna Christie), his translations of Molière and Brecht's poems for Mother Courage and Rise and Fall of the City of Mahagonny, and, above all, his published translation of O'Neill's Desire Under the Elms (Europa-América, 1959).

Jorge de Sena translated Long Day's Journey Into Night in 1957, less than two years after Carlotta Monterey O'Neill released the play for publication and for production - first to the Royal Dramatic Theater of Stockholm, which produced it on February 2, 1956, and then to José Quintero, who staged it in New York on November 7, 1956. In late-November 1957, Sena began work on his version of Neill's play, sending off from Lisbon each day's pages to António Pedro, the director of the Teatro Experimental, who was committed to a January 4, 1958 opening in Porto. Sena finished his translation within a month, and Pedro's production opened on schedule. In midApril of the same year, the production was moved to Lisbon for a three-day run. Unable to travel to Porto in January, Sena saw the production for the first time during its brief Lisbon run.

Sena expected to publish his translation imminently, even announcing in print that he was reserving further commentary on the play for the preface that would accompany its publication. But the preface was never written, and the translation remained unpublished for thirtyfive years. It appears, finally, as the seventeenth title in Livros Cotovia's "Theater" series.

Sena's willingness to take on the daunting task of translating O'Neill's greatest play on such

\footnotetext{
* Brown University.
} 
short notice and his success in bringing off the task on schedule - it was finished on Christmas Day 1957 - deserve to be seen for the great acts of good will and charity that they were. It is virtually inconceivable that anyone in Portugal at that time and working within the timeconstraints imposed upon him, could have come close to matching Sena's achievement. Yet the quality of his translation nowhere fails ro reflect his own passionate esteem for the American playwright's work.

In lieu of Sena's unwritten preface, Mécia de Sena has chosen to reprint his "O Testamento de Eugene O'Neill", a piece Sena published in Jornal de Notícias (Porto) on January 12, 1958, during the play's run in original production. Here we encounter none of the detailed discussion of the translator's engagements with O'Neill's text that one of Sena's own prefaces would have afforded us. What we do get are the critic's thoughts on the preeminence of O'Neill among American playwrights and the primacy of Long Day's Journey into Night in the O'Neill canon. "I do not know who it was that said that the great dramatists end up always by writing the essential play of their own lives", writes Sena, "the one that represents more than any other that examination of conscience, that confession, the Final Judgment. That play which, if not the final one written, stands as if it were, constituting a spiritual testament in dramatic form, a critical exposition of human life dedicated to the theater and - one and the same theater identified with Life." For O'Neill, Long Day's Journey was this final play, one in which, as Sena says, "along the length of a frightening day in four acts and five scenes, with everything happening to those people, nothing happens, save perhaps the tragedy of grace denied and lost."

Sena's translation - direct, clear, and supple - is well up to the original. If liberties appear to have been taken with the original - and there are, arguably, minor instances of this - such license is always informed. It is good to have this translation in print. If publication comes thirty-five years after the fact, we can content ourselves with saying - still again - better late than never. 